\title{
A Teaching-Learning Initiative with Tablet Computing
}

\author{
Beth Ann Swan, PhD, CRNP, FAAN \\ Thomas Jefferson University \\ Kellie Smith, EdD, RN \\ Thomas Jefferson University \\ Anthony J. Frisby, PhD \\ Thomas Jefferson University \\ Kathryn Shaffer, MSN, RN, CNE \\ Thomas Jefferson University \\ Mary Hanson-Zalot, MSN, RN \\ Thomas Jefferson University \\ Follow this and additional works at: https://jdc.jefferson.edu/nursfp \\ Part of the Education Commons, and the Nursing Commons \\ Let us know how access to this document benefits you
}

\section{Recommended Citation}

Swan, PhD, CRNP, FAAN, Beth Ann; Smith, EdD, RN, Kellie; Frisby, PhD, Anthony J.; Shaffer, MSN, RN, CNE, Kathryn; and Hanson-Zalot, MSN, RN, Mary, "A Teaching-Learning Initiative with Tablet Computing" (2012). College of Nursing Faculty Papers \& Presentations. Paper 55.

https://jdc.jefferson.edu/nursfp/55

This Article is brought to you for free and open access by the Jefferson Digital Commons. The Jefferson Digital Commons is a service of Thomas Jefferson University's Center for Teaching and Learning (CTL). The Commons is a showcase for Jefferson books and journals, peer-reviewed scholarly publications, unique historical collections from the University archives, and teaching tools. The Jefferson Digital Commons allows researchers and interested readers anywhere in the world to learn about and keep up to date with Jefferson scholarship. This article has been accepted for inclusion in College of Nursing Faculty Papers \& Presentations by an authorized administrator of the Jefferson Digital Commons. For more information, please contact: JeffersonDigitalCommons@jefferson.edu. 


\title{
As submitted to:
}

\section{CIN: Computers, Informatics and Nursing}

\author{
And published as:
}

A Teaching-Learning Initiative with Tablet Computing

Volume 30, Issue 9, September 2012, pp. 449-453.

DOI: 10.1097/NXN.0b013e31826ac8de

Swan, Beth Ann PhD, CRNP, FAAN; Smith, Kellie

EdD, RN; Frisby, Anthony J. PhD; Shaffer, Kathryn MSN,

\author{
RN, CNE; Hanson-Zalot, Mary MSN, RN \\ Jefferson School of Nursing
}

Thomas Jefferson University, Philadelphia, PA

- Creating the Infrastructure

- Planning for Implementation

- Student Considerations

Mobile computing and electronic books are the top emerging technologies to impact

higher education. ${ }^{1}$ The rapid expansion of technology in the health care setting has created a 
growing recognition that there is a need for adoption of a sound set of innovative teachinglearning strategies related to information management and technology applications in undergraduate nursing curriculum. Success in these technology-related strategies will rest on the degree to which schools comprehensively integrate technology with teaching-learning strategies in the undergraduate nursing curriculum.

Tablet computing has the potential to enhance educational experiences by providing a delivery option for teaching and learning practices that enable learners to interact with content, and each other, in immediate and seamless ways. ${ }^{2}$ The literature that exists on integrating tablet computers in the health professions focuses on the use of tablet computing for teaching medical students and enhancing resident clinical rotations. ${ }^{3-6}$ This paper describes the stages of a tablet computing integration initiative in a school of nursing including: 1) creating the infrastructure; 2) planning technology requirements; 3) designing faculty development sessions focused on curricular integration; and 4) building ongoing communication and support for students.

\section{Background}

At our university we have an Educational Technology Advisory Group (ETAG) that is a forum for discussing educational technology and finding opportunities to pilot and evaluate their use on campus at an urban, academic health science center. This group is chaired by the Director of Academic and Instructional Support and Resources (AISR) and includes representatives from each of the University's six schools and colleges and the Education Services group, a division of AISR which maintains responsibility for the educational technologies on campus. ETAG had been monitoring the use of mobile computing at other institutions, and felt that tablet computing presented opportunities for student learning that previous smart phone and personal digital devices (PDDs) did not, including computer-based testing. The School of Nursing has used 
PDDs and smart phones in its undergraduate nursing program for over five years. These devices provided convenient reference tools for practicing clinicians and prepared graduates with point of care technology skills as they entered the nursing workforce.

It was anticipated that multiple advantages would be gained by introducing a larger tablet device into the curriculum. The larger tablet device had the potential to provide easier access to full text books and journals, perhaps eliminating or reducing the need for printed materials. Additionally, the tablets might also be useful for computer-based exams and an alternative to the hand held audience participation devices already employed in the classrooms. At the January 2011 ETAG meeting, the School of Nursing offered to pilot tablet computing devices (Apple's iPad2) on campus with one of its undergraduate programs, the Facilitated Academic Coursework Track (FACT), an intensive 12-month BSN program for students with prior baccalaureate degrees. As the FACT class would matriculate in May 2011, the authors had 14 weeks to plan and implement this pilot initiative.

The University's Chief Information Officer (CIO) provided funding to help offset the student cost for purchasing the iPad2, the School Dean provided funding for faculty devices, and Education Services and University Information Technology (IT) agreed to provide support services for faculty development and student setup. Goals were established along with plans for regular data collection from students and faculty. The goals for the tablet computing initiative included measuring student satisfaction in relation to using the tablet as 1) an e-book reader compared to traditional printed text books; 2) a tool for audience participation; 3) a reference tool used in classroom exercises, simulation/laboratory setting, and clinical settings; 4) as an option for computer-based testing; and 5) assessing the tablet's value compared to other form factors (PDDs or Smart Phones) in the classroom, simulation/laboratory, and clinical settings. 
Additional goals included measuring faculty satisfaction with using the tablets in the classroom, simulation/laboratory setting, and clinical settings; as well as satisfaction with faculty development support and resources. Student and faculty satisfaction with technical support for using the tablets on campus was also an important goal of the initiative.

\section{Creating the Infrastructure}

The first step in the tablet computing integration initiative was securing needed human and technology resources. First, the authors identified and established required infrastructure and system requirements including campus network considerations such as wireless access spots and upgrades to classrooms; IT support; student access to home computing for synching; access to iTunes account; manufacturer's services agreement; and device battery life of 8 to 10 hours. Next, the authors secured intramural grant funding and University support. Revisions to the current policy and procedures that address mobile computing in the classroom, simulation/laboratory, and clinical settings were made in regards to infection control, loss prevention, and password protection. In examining infrastructure requirements for this initiative, critical functions identified were technology planning and acquisition, including vendor communication about book and product compatibility; faculty development and curricular integration; and student distribution plan and technology support.

\section{Technology Planning}

The authors identified and established system and network requirements. University IT and Education Services began testing the existing wireless access points in the classrooms used by the program. Not surprisingly, even though the rooms had been renovated just two years ago, it was difficult to get more than a couple dozen devices to respond in a timely enough manner to be acceptable. New access points were purchased and installed to meet the anticipated demands 
of 150+ devices; two classrooms were ready for use in May 2011. All students were required to purchase the manufacturer's service agreement including education support for 12 hours per day, seven days per week; and all students and faculty were required to install "find my iPad." In addition, the University uses Blackboard as its learning management system. Blackboard has a mobile application available and some students chose to use it instead of the Safari web browser which comes on the iPad. In addition, mobile management systems were explored.

Another important technology planning step was working with vendors. Book vendors advertised e-books but books were not "readable" on the tablet for a variety of reasons. For example, textbooks were not formatted for the screen; rather than a student viewing a textbook page snapshot, the screen display was text dense. Furthermore, tables and figures were provided as links requiring students to leave the page and open links out of context with the page.

In addition, videos were not able to be downloaded to the tablet, however, the School received permission to digitize the videos and load/post through iTunes $\mathrm{U}$ (http://www.apple.com/education/itunes-u/). Through this venue, students had access to 146 two-minute lab-skill videos that allowed them to brush up instantly on topics like wound care and catheter placement. The computer-based testing (CBT) product used by the School was not available for the iPad2 at the outset, however, faculty worked intensively with the CBT vendor. Now computer-based tests are deployed to the tablets and all students are able to complete the exams in one location in a proctored environment. Another consideration was the University's use of the Turning Technologies audience response program and devices. Turning Technologies had an iPad2 application available but the School felt the cost was too much to ask students to purchase, therefore the School purchased this application for each student.

\section{Human Considerations}


While there were many technology considerations, equally if not more important were the human considerations related to faculty development and student communication, support, and use.

\section{Faculty Development and Curricular Integration}

An essential step for faculty comfort was to deploy the devices to faculty as soon as possible. However, with the introduction of the iPad2 in March 2011, a decision was made to wait and purchase the second generation device. In the meantime, a formal plan for faculty development was initiated that included suggestions for tablet computing curricular integration. Expert faculty facilitators and super-users planned and conducted a comprehensive faculty orientation that included the development and distribution of a faculty user manual and an initial set-up checklist. In addition, 1:1 support and training were offered initially and throughout the academic year for all teaching teams. Important to the project's success was full curricular integration. Hence, many brainstorming integration sessions were held that explored course objectives and tablet computing integration strategies. Some examples of classroom, simulation/laboratory, and clinical integration activities are listed in Table 1.

\section{Student Communication, Distribution, Ongoing Support}

Integral components to the tablet computing implementation project were the use of appropriate communication systems, distribution plans, training, development, and ongoing support for students. These strategies called for detailed orientation and support initially and throughout the initiative. Students received prior notification about the tablet computing initiative in the FACT introductory welcome letter outlining system requirements, procedures for purchasing devices as part of the equipment bundle through the University bookstore, expectations of teaching-learning strategies integrating the tablet, and an orientation schedule. 
This information was reviewed again in-person at the FACT New Student Dinner in early April 2011.

In addition, students participated in two full days of extensive orientation workshops and had ongoing group and 1:1 support as described in the Box. Upon matriculation in mid-May 2011, students were asked to complete a short survey. Fifty percent of the incoming FACT students were MAC users and 50\% were PC users. Ninety-one percent of students had wireless Internet access at home and $77 \%$ used an iTunes account. Sixty-six percent revealed that they had prior experience with use of handheld devices for personal use, and only two percent had used a handheld device for education reasons. The majority of students reported being comfortable or very comfortable with using technology $(51 \%), 39 \%$ reported being novices but learning, while ten percent reported being uncomfortable. Eighty-eight percent of students described themselves as early or middle adopters users of technology.

Lastly, a thorough evaluation plan was developed in the form of anonymous satisfaction surveys, focus group sessions, classroom and clinical observations, and course evaluations. Data was collected after orientation, mid-year, and at the end of the academic year. This formative evaluation assisted in real-time revising and adapting the iPad2 initiative to meet the needs of students and faculty.

\section{Lessons Learned}

Many lessons were learned since the inception of the pilot project in May 2011 concerning infrastructure support, the student experience, and faculty feedback using tablet technology in the classroom and clinical setting. FACT student enrollment for the 2011 academic year was 130 students. However, periodic checks on the network indicated as many as 176 devices being simultaneously connected. No doubt several students setup their smart phones with the wireless 
information distributed for their iPads. Intermittent monitoring of connection points during class times is warranted in order to avert connection disruptions that interfere with interactive learning sessions planned by faculty. Additionally, it was learned that a variety of clinical settings did not support connectivity for the tablet devices. This interruption in tablet use was compensated by using wired computers in the clinical arena to gain Internet access as needed.

Perhaps the most challenging part of this initiative was noting that the majority of eBooks purchased by students as required for their courses were not optimal for viewing on the iPad2. Students reported formatting issues involving page numbers not corresponding to print text versions, shifting of charts and diagrams, as well as content being cut off of pages. Early communication of difficulties resulted in an upgrade to electronic text supports allowing students to highlight and take notes in their eBooks. One vendor supplying core referential texts was able to generate an application that greatly improved the viewing experience for students on the tablet. Conversely, another book vendor provided three different applications to remediate their e-book viewing but this did not improve the viewing experience for the students.

Some texts in the required book packet included instructional videos for students. Permission was sought from the publisher to convert these videos to a format that worked on the iPad2 device; hence the support of AISR, and continued communication with text vendors remained crucial to prompt continued improvement and functionality of the tablet devices. At the present time, faculties are engaged in text selection for the upcoming academic year. While they are previewing new title options within their specialties, they are also considering the quality of publishers' eBook versions of these same texts from alternative vendors and distributors. Before embarking on this type of initiative, it is critical to determine vendor readiness and build in time to talk through problems with vendors. 
The comfort level of faculty using the iPad2 is essential to supporting the student experience. As some faculties are more fluent with technology than others, we found that scheduling forums for sharing questions and ideas for integration throughout the academic year was helpful. Critical for faculty is to keep the curriculum as the focal point with technology playing a supporting role. Additionally, faculty need to be ready to discuss the purposes and advantages of using this technology with clinical affiliates who may perceive that students are using the devices in patient care areas for personal use rather than care delivery. Furthermore, full-time faculty need to orient part-time clinical instructors to the intended purposes and use of the tablet devices now employed by students.

Lastly, the challenge of synching devices and data storage was lessened with the initiation of iCloud computing. iCloud technology is a virtual storage system that by automatically and securely storing content such as photos, documents, and email "in the cloud," permits access of this content on different devices. The cloud is a distant server that serves as the storage device.

As the initiative entered the final quarter, plans were underway to expand the use of tablet computing for the incoming FACT class, as well as junior students in the traditional prelicensure program. The School will pilot tablet computing with Doctoral of Nursing Practice students in summer 2012, and then plan for a pilot with the Masters of Science in Nursing students.

\section{Conclusion}

During the 12-months that the tablet computing initiative was implemented, technology continued to evolve rapidly with tablets quickly becoming a defacto part of health professions education. While current students and faculty were initially challenged with integrating tablet 
computing into the undergraduate nursing curriculum, by year's end students had embraced the tablets and faculty were identifying many more teaching-learning experiences for the upcoming academic year. With 1:1 tablet computing becoming a mainstay of kindergarten through $12^{\text {th }}$ grade education, the day will soon come when young nursing and health profession students demand this kind of technology as part of their education learning experience. 


\section{References}

1. Johnson, L., Smith, R., Willis, H., Levine, H., \& Haywood, K. (2011). The 2011 Horizon Report. Austin: The New Media Consortium. Retrieved from http://net.educause.edu/ir/library/pdf/HR2011.pdf. 2. Barnes, J., Herring, D., Nelson, G., \& Notar, C. (2010). Using mobile devices in the classroom. In J. Sanchez \& K. Zhang (Eds.). Proceedings of World Conference on e- $\quad$ learning in corporate, government, healthcare, and higher education 2010 (pp.607-609).

Chesapeake: Association for the Advancement of Computing in Education. Retrieve from http://www.editlib.org/p/35611.

3. Berger, E. (2010). The iPad: Gadget or medical godsend? Annuals of Emergency Medicine, 56(1), 21A-22A.

4. Kiser, K. (2011). The iPad project. Minnesota Medicine, 94(4), 12.

5. Robinson, J.D. (2012). The skeptical technophile: iPad review. Journal of Digital Imaging, 25, 365-368.

6. Tanaka, P.P., Hawrylyshyn, K.A., \& Macario, A. (2012). Use of tablet (iPad) as a tool for teaching anesthesiology in an orthopedic rotation. Revista Brasileira de Anestesiologia, 62(2), 214-222. 